\title{
VTR Startup Fuel Paper for NFSM
}

\author{
Douglas C. Crawford, PhD, Steven L. \\ Hayes, Jeffery J. Powers
}

February 2018

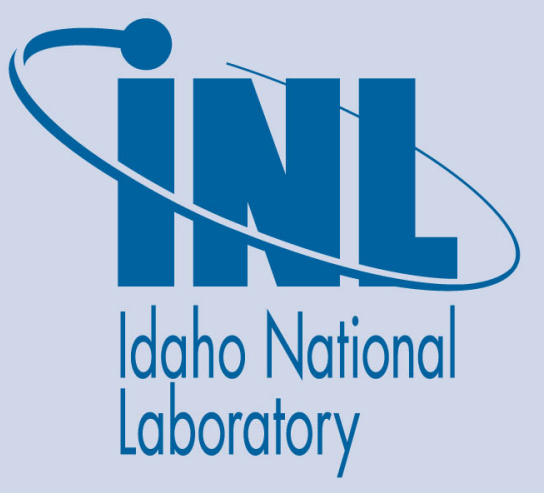

The INL is a U.S. Department of Energy National Laboratory operated by Battelle Energy Alliance 


\section{VTR Startup Fuel Paper for NFSM}

Douglas C. Crawford, PhD, Steven L. Hayes, Jeffery J. Powers

February 2018

Idaho National Laboratory Idaho Falls, Idaho 83415

http://www.inl.gov

Prepared for the

U.S. Department of Energy

Under DOE Idaho Operations Office

Contract DE-AC07-05ID14517 


\title{
A Proposed Start-up Fuel for the Versatile Test Reactor
}

\author{
Douglas C. Crawford, PhD/Steven L. Hayes, ${ }^{*}$ Jeffery J. Powers ${ }^{\dagger}$ \\ *Idaho National Laboratory, 1955 N. Fremont Ave./P.O. Box 1625, Idaho Falls, ID 83415, \\ Doug.Crawford@inl.gov/Steven.Hayes@inl.gov \\ †Oak Ridge National Laboratory, 1 Bethel Valley Road/P.O. Box 2008, Oak Ridge, TN 37830, powersjj@ornl.gov
}

\section{INTRODUCTION}

A 2017 report issued by the Department of Energy Office of Nuclear Energy's (DOE-NE) Nuclear Energy Advisory Committee (NEAC) discussed needs and requirements for a new test reactor in the U.S. ${ }^{1}$ The report included a recommendation to "proceed immediately with pre-conceptual design planning activities to support a new test reactor (including cost and schedule estimates)." In response, DOE-NE initiated a research and development effort to inform a decision on the further development of a fast test reactor be initiated, with emphasis on providing a fast-spectrum irradiation capability. The R\&D effort is intended to identify a reference concept and estimate the cost for a versatile experimental capability that provides fast-spectrum irradiation testing of nuclear fuels and structural materials under irradiation environments representative of future advanced nuclear reactors. ${ }^{2}$ This reactor is currently known as the Versatile Test Reactor (VTR). Although work performed to date toward establishing a reference conceptual design is pre-decisional, certain design features and technology options are assumed to allow subsequent cost estimating. A particular objective of the current effort is to incorporate well-known technologies into the test reactor, contributing to the highest possible reactor reliability and uncertainty reduction. One of the technology options being considered is the design of the startup driver fuel.

U.S. fast reactor fuel experience is overwhelmingly with metal alloy fuel and mixed oxide or $(\mathrm{U}, \mathrm{Pu}) \mathrm{O}_{2}$, although many other fuel forms have been investigated in varying degrees. ${ }^{3}$ That experience includes production of metal alloy and mixed oxide fuel rods and assemblies in multiple, large campaigns and at ongoing production rates, meeting production schedules and specifications necessary to fuel reactors such as Fermi I, Experimental Breeder Reactor II, and the Fast Flux Test Facility., ${ }^{45}$ The performance and limitations of those fuel forms, including the degradation mechanisms leading to fuel failure, are well known, and design parameters providing good performance and fuel reliability have been identified. ${ }^{1}$ The experience base supporting either of those two startup fuel designs is sufficient to support a safety case for a new test reactor (supplemented by qualification of new fuel fabrication lines and fuel surveillance during reactor operation). This paper summarizes a proposed metal fuel design for the VTR startup fuel.

\section{BASIS}

Reasons that favor a metal alloy fuel design (in which the fuel slug is thermally bonded to the cladding interior wall by sodium that fills the fuel-cladding annulus) include the following:

- Under current fissile material enrichment constraints, the higher heavy-metal density of metallic fuel offers more core design options that are capable of providing desired irradiation conditions (i.e., fast neutron flux with relatively small core size) from a variety of fissile feed options than are provided by oxide fuel. To achieve similar performance levels under the same fissile enrichment constraints, the use of oxide fuel instead of metallic fuel would require a larger core.

- Safety analyses for oxide and metallic fuels have shown there can be significant differences in (low probability) severe accident consequences due to neutronic and thermophysical properties of the fuel and their compatibility with sodium, with particular advantages for metallic fuel. ${ }^{6}$

- U.S. experience with metallic fuel is very extensive, including 30 years of EBR-II operating experience using metallic driver fuels in a whole core application, qualification of metallic driver fuels for larger sodium fast reactors through full-size subassembly demonstrations, and even use of metallic fuels in a commercial sodium-cooled fast reactor. This U.S. experience is adequate to support a licensing case in support of a new fast test reactor.

- Fabrication of metallic fuel requires fewer process steps and substantially less floor space than does fabrication of oxide fuel, and quality assurance requirements for metallic fuel are generally much less stringent. ${ }^{4,5}$ Historically, metallic fuels were fabricated for EBR-II by two different commercial suppliers using different fabrication methods, as well as being fabricated at the EBR-II site in multiple facilities using several different casting furnaces, demonstrating the in-reactor performance of metallic fuels to be relatively insensitive to fabrication route. If necessary, some or all of the driver fuel could be fabricated using existing DOE facilities, minimizing the need for new fuel production space (which would be more expensive if plutonium is part of the fissile supply). 
- At least three private-sector advanced reactor developers active today call for a variant of metallic fuel in their advanced reactor concepts, based on the prior experience and programs. No developers of advanced fast-spectrum reactors in the U.S. currently propose to use MOX fuel. Therefore, the technology based around a metallic fuel for the test reactor will provide mutual benefit for the deployment of these advanced reactor concepts (operating experience, supply chain development, and licensing infrastructure).

\section{PROPOSED DESIGN}

The startup fuel initial concept proposed for the VTR is U$20 \mathrm{Pu}-10 \mathrm{Zr}$ metallic alloy fuel clad in either $316 \mathrm{SS}$ or HT9. Although the ferritic-martensitic steel HT9 is the preferred cladding material for high burnup applications, the austenitic steel $316 \mathrm{SS}$ will perform reliably to 10 at.\% burnup, and both cladding materials were used in previously qualified fuel designs. For similar reasons, subassembly ducts will be either 316 SS or HT9. Should the fuel pins be wire-wrapped for spacing within the subassembly, consistent with previously qualified fuel designs, then wire material would be either $316 \mathrm{SS}$ or HT9, the same as the cladding/duct materials.

The fuel-cladding gap should be sized to yield a smeared density of $75 \%$ to accommodate fuel swelling up to 10 at. $\%$ burnup (or more). For adequate heat transfer through the gap, the gap must be filled with liquid sodium. The fuel pin must include a fission gas plenum above the fuel stack to accommodate approximately $80 \%$ of generated fission gases, which will be released by the fuel matrix during irradiation; although the length of the fission gas plenum region will ultimately be determined from the desired burnup limit and acceptable cladding stresses that are cladding material dependent, experience indicates that the length of the fission gas plenum should exceed that of the fuel (i.e., core) height.

Table 1. Parameters of a Proposed Metal Fuel Design for the VTR

\begin{tabular}{|l|l|}
\hline Design Feature & Description \\
\hline Nominal Composition (wt.\%) & U-20Pu-10Zr \\
\hline Fuel Theoretical Density (\% TD) & 100 \\
\hline Fuel Smeared Density (\% TD) & 75 \\
\hline Plenum-to-Fuel Volume Ratio & 1.4 \\
\hline Fuel-Cladding Bond & Sodium \\
\hline Cladding Material & HT9 or 316 SS \\
\hline Duct Material & HT9 or 316 \\
\hline
\end{tabular}

\section{CONCLUSION}

Should the U.S. decide to go forward with the design, construction, and operation of a fast-spectrum test reactor similar to the VTR, then a metal fuel design can provide a suitable startup fuel for the reactor.

\section{REFERENCES}

1. Assessment of Missions and Requirements for a New U.S. Test Reactor, Nuclear Energy Advisory Committee, U.S. Department of Energy, February 2017.

2. Versatile Test Reactor Program Requirements Document, Idaho National Laboratory report no. INL/EXT-17-4320, September, 2017.

3. D. C. Crawford, D. L. Porter, S. L. Hayes, "Fuels for Sodium-cooled Fast Reactors: US Perspective," Journal of Nuclear Materials, Vol. 371, 2007, pp. 202-231.

4. D. E. Burkes, et al., "A US Perspective on Fast Reactor Fuel Fabrication Technology and Experience. Part I: Metallic Fuels and Assembly Design," Journal of Nuclear Materials, Vol. 389, 2009, pp. 458- 469.

5. D. E. Burkes, et al., "A US Perspective on Fast Reactor Fuel Fabrication Technology and Experience. Part II: Ceramic Fuels," Journal of Nuclear Materials, Vol. 393, 2009, pp. 1-11.

6. R. Wigeland, J. Cahalan, "Fast reactor fuel type and reactor safety performance," Global 2009 conference, Paris, France, September 6-11, 2009. American Nuclear Society. 